\title{
HUBUNGAN KONSUMSI MAKANAN DENGAN POLA BUANG AIR BESAR PADA ANAK USIA 6-12 TAHUN
}

\author{
${ }^{1}$ Annisa Rahmah, ${ }^{2}$ Ahmad Yamin, ${ }^{3}$ Wiwi Mardiah \\ ${ }^{1}$ Alumni Fakultas Keperawatan Universitas Padjadjaran, \\ ${ }^{2,3}$ Staf Dosen Fakultas Keperawatan Universitas Padjadjaran
}

\begin{abstract}
Abstrak
Penelitian ini bertujuan untuk mengetahui adanya hubungan konsumsi makanan dengan pola BAB pada anak usia 6-12 tahun di SDN Raya Barat Kota Bandung. Penelitian ini menggunakan metode kuantitatif deskriptif. Total populasi anak usia 6-12 tahun di SDN Raya Barat sebanyak 1.021 anak, dengan jumlah responden sebanyak 100 anak, didapatkan melalui teknik stratified random sampling. Data diperoleh dengan teknik decomentary-historical menggunakan instrumen dekomentasi Food Record. Data yang didapatkan kemudian diolah menggunakan program nutrisurvey dan uji Chi-Square. Didapatkan bahwa tidak ada hubungan antara konsumsi makanan dengan pola BAB pada anak usia 6-12 tahun dengan $\alpha>0,05$. Walaupun demikian, kita dapat mengetahui bahwa hampir seluruh responden mengonsumsi serat kurang dari nilai cukup (20-31 g/hari) sebesar 99\% (99 anak) dan frekuensi BAB kurang dari 4 kali dalam seminggu sebanyak 52\% (52 anak). Penyuluhan tentang manfaat dan pengaruh konsumsi serat dan asupan cairan pada anak di sekolah oleh pihak sekolah yang bekerja sama dengan pihak puskesmas setempat kepada orang tua murid SDN Raya Barat Kota Bandung dapat menjadi salah satu cara untuk memberikan pengetahuan kepada masyarakat.
\end{abstract}

Kata Kunci: anak usia 6-12 tahun, Karbohidrat, Serat, Pola BAB

\begin{abstract}
This study intend to khow relationship between food consumption and pattern of defecation in children aged 6-12 years at SDN Raya Bandung. This study used a descriptive quantitative. The total population of children aged 6-12 years in SDN Raya Barat as much as 1,021 children, the number of respondents as many as 100 children were obtained trough stratified random sampling technique. Data obtained trough decomentary-historical techniques using instruments decomentation Food Record. The data obtained was processed using the program nutrisurvey and test Chi-Square. It was found that there was no association between the foods consumption with pattern of defecation in children aged 6-12 years with $\alpha>0.05$. However, we can know that almost all respondents consume less fiber than enough value (20-31 g/day) was $99 \%(n=99)$ and the frequency of bowel less than 4 times a week as much as $52 \%(n=52)$. Counseling about the benefits and the effect of fiber and fluid intake for children in school by the school in collaboration with the local health center to parents SDN Raya Barat Bandung can be one way to provide knowledge to the public.
\end{abstract}

Key word: Carbohydrate, Children aged 6-12 years, fiber, pattern of defecation

\section{PENDAHULUAN}

Eliminasi merupakan salah satu kebutuhan dasar manusia dan merupakan aspek penting untuk menjaga keseimbangan fungsi organ tubuh. Perubahan eliminasi dapat menyebabkan gangguan sistem gastrointestinal dan sistem lainnya (Potter \& Perry, 2005). Faktor yang paling memengaruhi pola $\mathrm{BAB}$ adalah konsumsi makanan terutama makanan-makanan yang mengandung serat (Nakaji et. al, 2002). Volume feses sangat berkaitan erat dengan asupan serat makanan. Volume feses yang lebih banyak akan lebih sering di evakuasi. Jika seseorang 
mengonsumsi banyak makanan berserat, maka waktu singgah feses yang melalui saluran pencernaan akan lebih cepat (Juffrie dkk, 2012).

Penelitian ini mengambil kasus konstipasi yang banyak terjadi pada anak usia 6-12 tahun. Hal tersebut dibuktikan dengan angka kejadian kasus konstipasi pada anak di dunia berada pada rentang 2\%-38\% (Inan et, al 2007 dalam Jennings et, al 2010). Selain itu, saat ini banyak anak yang mengonsumsi makanan tinggi energi tetapi rendah nutrisi dan kurang mengonsumsi sayur dan buah (McGowan, et al., 2013), contohnya makanan-makanan cepat saji. Hal tersebut disebabkan juga oleh kurangnya pengawasan orang tua terhadap pemilihan makanan yang dikonsumsi oleh anak dan karena kesibukan pekerjaan orang tua yang mengakibatkan anak kurang mengonsumsi makanan berserat (Puspamika\&Sutiari, 2014). Tingginya konsumsi makanan berenergi tinggi tanpa diimbangi dengan konsumsi makanan yang mengandung serat yang cukup dapat berisiko terjadinya polip pada usus (Miskovitz and Betancourt, 2005). Pola konsumsi makanan yang buruk pada anak-anak juga dapat menyebabkan terjadinya obesitas, jika tidak ditangani dengan baik akan meningkatkan risiko terjadinya penyakit degeneratif pada anak (McGowan et al., 2013).

Mengonsumsi makanan yang tinggi serat akan membantu meningkatkan pola eliminasi yang normal jika faktor-faktor yang memengaruhi eliminasi fekal ini normal (Miskovitz and Betancourt, 2005). Menurut Potter and Perry (2010), frekuensi buang air besar pada anak-anak berkisar 1-3 kali per hari bagi yang rutin mengonsumsi susu. Serat merupakan salah satu kandungan yang ada dalam karbohidrat kompleks. Serat sangat penting sekali dalam sistem pencernaan salah satunya adalah mengurangi gas yang ada dalam pencernaan (Somnath et al., 2012) dan berpengaruh dalam pengaturan konsentrasi gula dan lemak dalam sistem peredaran darah (Schlenker and Roth, 2011).

Anak usia 6-12 tahun tumbuh dengan lambat dan menetap sehingga kebutuhan energinya pun menurun secara bertahap per unit berat badan. Selain nafsu makan yang cenderung stabil dan asupan makanan yang lebih bervariasi. Anak usia sekolah sering kali mengonsumsi makanan di sekolah yang tidak dapat diawasi (Potter and Perry, 2010). Pada usia 6-12 tahun pula anak sudah pandai menentukan makanan yang akan dimakan karena sudah mengenal lingkungan, biasanya anak akan lebih menyukai makanan instan atau cepat saji (fast food) (Ratnasari, Dewi, dan Yekti, 2012).

Studi pendahuluan yang bertempat di SDN Raya Barat Kota Bandung didapatkan hasil bahwa 74 dari 100 orang anak memiliki frekuensi BAB kurang dari 4 kali dalam seminggu dan dari 10 orang anak yang diwawancarai tentang konsumsi makanan berserat, semuanya menjawab kurang mungonsumsi sayur atau buah-buahan.

Berdasarkan hasil observasi dan wawancara pada beberapa anak dan orangtua siswa di beberapa Sekolah Dasar di Kota Bandung, didapatkan bahwa pedagang makanan yang paling banyak adalah pedagang makanan ringan dan makanan yang berbahan dasar tepung terigu. Anak-anak pun tidak dibiasakan oleh orang tuanya membawa makanan dari rumah sehingga ketika anak merasa lapar, anak akan lebih memilih jajan jajanan yang ada di sekitar sekolah. Beberapa orang tua siswa mengatakan sengaja memberikan uang jajan kepada anaknya karena merasa kasihan kepada anaknya jika anaknya melihat temannya yang jajan sedangkan dirinya sendiri tidak jajan. Tetapi tindakan tersebut tidak diimbangi dengan pemantauan terhadap jajanan-jajanan apa saja yang anaknya beli baik di lingkungan sekolahnya maupun lingkungan tempat tinggal.

\section{METODE PENELITIAN}

Metode penelitian yang digunakan adalah metode kuantitatif deskriptif dengan desain yang digunakan ialah korelasi prediktif. Dalam penelitian ini peneliti tidak mendapatkan hubungan antara konsumsi makanan dengan pola buang air besar (BAB) pada anak usia 6-12 tahun di SDN Raya Barat Kota Bandung. Populasi penelitian ini adalah anak sekolah yang 
berusia 6-12 tahun yang bersekolah di SDN Raya Barat. Jumlah populasi anak yang berusia 612 tahun di SDN Raya Barat sebanyak 1.241 anak dan metode dalam pengambilan sampel menggunakan metode stratified random sampling, lalu untuk mendapatkan jumlah minimal sampel menggunakan rumus slovin dan didapatkan hasil sebanyak 100 orang anak.

Peneliti menggunakan metode dokumentasi yaitu Diet History Food Record yang digunakan oleh Nationwide Food Consumption Survey (NFCS) untuk mendapatkan status nutrisi populasi pada tahun 1994-1996 yang dimodifikasi oleh peneliti untuk mengetahui waktu BAB pada responden dengan pertimbangan keinginan peneliti untuk melihat frekuensi buang air besar pada anak selama seminggu.

\section{HASIL PENELITIAN}

Tabel 1. Tabel Distribusi Frekuensi Karakteristik Responden

\begin{tabular}{ccc}
\hline Karakteristik & Frekuensi & (\%) \\
\hline Usia & & \\
4- 6 tahun & 3 & $3 \%$ \\
7-9 tahun & 61 & $61 \%$ \\
10-12 tahun & 36 & $36 \%$ \\
\hline Jenis Kelamin & & \\
Laki - Laki & 47 & $47 \%$ \\
Perempuan & 53 & $53 \%$ \\
\hline Total & 100 & $100 \%$ \\
\hline
\end{tabular}

Dari tabel 1 dapat diketahui bahwa jumlah responden terbanyak terdapat pada kolompok usia 7-9 tahun dengan persentase sebesar $61 \%$ dan jumlah responden terbanyak adalah anak perempuan sebanyak $53 \%$.

Tabel 2. Data Konsumsi Karbohidrat pada Anak Usia 6-12 Tahun

\begin{tabular}{ccc}
\hline Kategori & Responden & $\%$ \\
\hline Kurang $(<120 \mathrm{~g})$ & 24 & 24 \\
Baik $(120-220 \mathrm{~g})$ & 43 & 43 \\
Lebih $(>220 \mathrm{~g})$ & 32 & 32 \\
\hline Total & 100 & 100 \\
\hline
\end{tabular}

Dari tabel 2 diatas dapat diketahui bahwa responden cenderung mengonsumsi cukup yaitu $120-220 \mathrm{~g} /$ hari yaitu sebanyak $43 \%$.

Tabel 3. Data Konsumsi Serat pada Anak Usia 6-12 Tahun

\begin{tabular}{ccc}
\hline Kategori & Responden & $\%$ \\
\hline Kurang $(<20 \mathrm{~g})$ & 99 & 99 \\
Baik $(20-31 \mathrm{~g})$ & 1 & 1 \\
\hline Total & 100 & 100 \\
\hline
\end{tabular}

Tabel 3 menunjukkan bahwa sebagian besar responden memiliki kecenderungan mengonsumsi serat kurang dari 20-31 g/ hari. 
Tabel 4. Data Frekuensi BAB pada Anak Usia 6-12 Tahun di SDN

\begin{tabular}{ccc}
\hline Kategori & Responden & $\%$ \\
\hline Kurang $(<\mathbf{4} \mathbf{x} / \mathbf{m g})$ & 52 & 52 \\
Baik $(\mathbf{4 - 9} \mathbf{x} / \mathbf{m g})$ & 48 & 48 \\
\hline Total & 100 & 100 \\
\hline
\end{tabular}

Dari tabel 4.4 dapat diketahui bahwa anak usia 12 tahun lebih cenderung memiliki frekuensi BAB kurang dari 4 kali dalam seminggu dengan persentase sebesar $52 \%$.

Tabel 5. Crosstabulation Konsumsi Karbohidrat dengan Pola BAB pada Anak Usia 6-12 Tahun

\begin{tabular}{|c|c|c|c|c|c|c|c|c|}
\hline \multirow{2}{*}{$\begin{array}{l}\text { Konsumsi } \\
\text { Karbohidrat }\end{array}$} & \multicolumn{4}{|c|}{ Frekuensi BAB } & \multirow[b]{2}{*}{ Total } & \multirow[b]{2}{*}{$\%$} & \multirow[b]{2}{*}{$x^{2}$} & \multirow[b]{2}{*}{$\begin{array}{l}\text { Asymp. } \\
\text { sig }\end{array}$} \\
\hline & Tidak Normal & $\%$ & Normal & $\%$ & & & & \\
\hline Kurang & 16 & 30,8 & 8 & 16,7 & 24 & 24 & 4,878 & 0,087 \\
\hline Cukup & 24 & 46,2 & 20 & 41,7 & 44 & 44 & & \\
\hline Lebih & 12 & 23,1 & 20 & 41,7 & 32 & 32 & & \\
\hline Total & 52 & 52 & 48 & 48 & 100 & 100 & & \\
\hline
\end{tabular}

Dari tabel 5 dapat dilihat secara proporsi bahwa responden yang mengonsumsi karbohidrat cukup dan kurang memiliki pola BAB kurang dari 4 kali dalam seminggu sebesar $77 \%$ dan yang mengonsumsi karbohidrat lebih dari $220 \mathrm{~g} / \mathrm{hari}$ memiliki frekuensi BAB dalam batas normal sebesar $41,7 \%$. Dari hasil tersebut didapatkan hasil output chi square test yang menampilkan hasil pengujian antara konsumsi karbohidrat dengan frekuensi BAB diperoleh hasil $\mathrm{X} 2$ hitung sebesar 4.878 dengan nilai signifikansi (Asymp. Sig. (2-sided)) sebesar 0,087. Jika dilihat dari hasil statistik tidak terdapat hubungan antara konsumsi karbohidrat terhadap pola BAB. Namun, berdasarkan hasil tabel dapat dilihat bahwa semakin banyak seseorang mengonsumsi karbohidrat, maka frekuensi BAB relatif lebih normal di bandingkan dengan yang mengonsumsi karbohidrat kurang ataupun cukup.

Tabel 6. Crosstabulation Konsumsi Serat dengan Pola BAB pada Anak Usia 6-12 Tahun

\begin{tabular}{cccccccccc}
\hline & & \multicolumn{9}{c}{ Frekuensi BAB } & & & \\
\cline { 3 - 8 } & & $\begin{array}{c}\text { Tidak } \\
\text { Normal }\end{array}$ & $\%$ & Normal & $\%$ & Total & $\%$ & X2 & $\begin{array}{l}\text { Asym } \\
\text { p. sig }\end{array}$ \\
\hline Kurang & Jumlah & 52 & 100 & 47 & 97,9 & 99 & 99 & 1,094 & 0,296 \\
Cukup & Jumlah & 0 & 0,0 & 1 & 2,1 & 1 & 1 & & \\
\hline Total & Jumlah & 52 & & 48 & & 100 & 100 & \\
\hline
\end{tabular}

Dari tabel 6 dapat dilihat bahwa responden yang memiliki pola BAB normal dengan tidak normal sama-sama mengonsumsi serat kurang dari $20 \mathrm{~g} / \mathrm{hari}$. Dari hasil tersebut didapatkan hasil output chi square test yang menampilkan hasil pengujian antara konsumsi serat dengan frekuensi BAB diperoleh hasil $X 2$ hitung sebesar 1.094 dengan nilai signifikansi (Asymp. Sig. (2-sided)) sebesar 0,296. Berdasarkan hasil statistik tersebut dapat dismpulkan bahwa antara konsumsi serat dengan pola BAB tidak terdapat hubungan. Walaupun demikian, 
kita dapat mengetahui bahwa anak usia 6-12 tahun di SDN Raya Barat Kota Bandung mengalami kekurangan serat.

Berdasarkan hasil tersebut, maka dapat disimpulkan dengan $\alpha>5 \%$ tidak terdapat hubungan antara konsumsi makanan dengan pola BAB pada anak usia 6-12 tahun di SDN Raya Barat Kota Bandung.

\section{PEMBAHASAN}

\section{Hubungan Konsumsi Karbohidrat dengan Pola BAB}

Penelitian ini didapatkan hasil bahwa anak yang mengonsumsi karbohidrat lebih dari yang di rekomendasikan yaitu 120-220 g/hari memiliki frekuensi BAB yang relatif normal yaitu 4-7 kali dalam seminggu. Penelitian ini sesuai dengan penelitian Brinkworth, Noakes, Clifton and Bird (2009) di Australia yang menyatakan bahwa seseorang yang mengonsumsi makanan rendah karbohidrat memiliki frekuensi $B A B$ yang lebih rendah dibandingkan dengan yang mengonsumsi makanan tinggi karbohidrat. Selain itu, Brinkworth, Noakes, Clifton and Bird (2009) juga menyatakan bahwa seseorang yang mengonsumsi makanan yang tinggi karbohidrat maka volume fesesnya juga akan lebih banyak. Volume feses ini selain dari serat yang dikonsumsi, tapi juga dapat berasal dari makanan yang mengandung zat pati yang tidak dapat dicerna semuanya oleh tubuh (Kozier et. al, 2010). Makanan yang zat patinya tidak dapat diserap semua oleh tubuh contohnya kentang, pisang, biji-bijian dan polong (Schlenker, 2011). Namun berdasarkan penelitian ini makanan yang paling sering dikonsumsi adalah nasi, mie instan dan roti tawar.

Jika dilihat dari hasil statistik yang menunjukkan $\alpha>0,05$ yang berarti tidak terdapat hubungan antara konsumsi karbohidrat dengan pola BAB pada anak usia 6-12 tahun. Hal ini dapat disebabkan oleh beberapa faktor seperti konsumsi minuman. Berdasarkan hasil penelitian ini hampir semua respoden mengonsumsi susu 1-3 gelas dalam sehari. Hal ini sesuai dengan anjuran My Pyramid for Kids for Younger Children dari U. S. Department of Agriculture, Food and Nutrition Service yang menganjurkan konsumsi susu atau produk olahan susu untuk anak adalah sebanyak 1 gelas per hari. Konsumsi Anak yang tidak mengonsumsi susu sama sekali memiliki frekuensi BAB kurang dari 4 kali dalam seminggu. Hal ini sesuai dengan hasil studi literatur yang menyatakan bahwa anak yang rutin mengonsumsi susu setiap hari memiliki peluang untuk buang air besar 1-3 kali per hari (Kozier et. al, 2010).

Selain itu, asupan cairan yang adekuat juga dapat membantu dalam penghancuran makanan yang kering saat proses pencernaan makanan di dalam lambung. Feses yang sehat membutuhkan 2.000-3.000 mL cairan perhari sehingga feses yang dihasilkannya menjadi lebih lembut dan berair (Kozier et. al, 2010). Asupan cairan yang adekuat juga memengaruhi pergerakan kimus dalam usus sehingga jika asupan cairan tidak adekuat maka perjalanan kimus akan melambat dan meningkatkan penyerapan cairan dari kimus kembali kedalam tubuh (Kozier et. al, 2010).

Berdasarkan penelitian ini, peneliti mendapatkan data bahwa anak usia 6-12 tahun memiliki kebiasaan minum 3-5 gelas per hari. Data tersebut tidak sesuai dengan anjuran asupan cairan pada anak dan remaja yaitu sekitar $2000 \mathrm{~mL}$ per hari (Feferbaum, 2012). Hal ini menunjukkan bahwa asupan cairan pada anak di SDN Raya Barat Kota Bandung belum terpenuhi dengan baik. Jika seseorang mengonsumsi air kurang dari kebutuhan per hari dapat mengakibatkan dehidrasi dan membuat feses menjadi kering dan keras sehingga saat berdefekasi harus menggunakan usaha yang lebih kuat (Kozier et. al, 2010)

Selain asupan cairan, faktor aktivitas fisik juga dapat memengaruhi pola BAB seseorang. Aktivitas fisik dapat menstimulasi pergerakan peristaltik sehingga kimus atau hasil pencernaan makanan dalam lambung yang melewati usus dapat bergerak dengan mudah (Potter\&Perry, 2009). Aktivitas fisik yang dianjurkan adalah selama minimal 30 menit per hari dan dilakukan selama $3 x$ dalam seminggu. Jenis aktivitas fisik yang dianjurkan untuk pemula 
dan lansia adalah berjalan, berepeda dan berenang dan untuk membakar kalori dapat melakukan aktivitas berlari atau lompat tali (Kozier, 2010). Menurut penelitian Nakaji et. al tahun 2002 di Jepang mengatan bahwa aktivitas yang paling efektif untuk meningkatkan peristaltik usus adalah berjalan kaki.

Kurangnya aktivitas fisik dapat menurunkan fungsi neurologi sehingga kontraksi otot perut, panggul dan peristaltik usus akan menurun dan menyebabkan konstipasi. Dalam beberapa kondisi, anak usia sekolah yang sedang bermain cenderung menunda untuk buang air besar walaupun keinginan untuk buang air besar itu sudah ada (Kozier et. al, 2010). Kondisi ini beresiko menurunkan rangsang neurologi untuk buang air besar. Bagainamapun kondisinya, kebutuhan eliminasi dalam hal ini adalah buang air besar tidak dapat dihindari (Gage\&Fernandes, 2009).

Walaupun demikian, pada dasarnya frekuensi $B A B$ seseorang ini sangat bersifat individual, mulai dari beberapa kali dalam sehari sampai beberapa kali dalam seminggu (Kozier et. al, 2010). Kebiasaan defekasi pada anak juga tidak akan jauh berbeda dengan kebiasaan mereka saat dewasa. Dalam penelitian ini responden dengan frekuensi BAB kurang dari 4 kali dalam seminggu sebanyak $52 \%$ dan $4-9$ kali dalam seminggu sebanyak $48 \%$. Hasil tersebut menunjukkan adanya kecenderungan bahwa anak-anak di SDN Raya Barat Kota Bandung mengalami konstipasi. Jika keadaan ini terus dibiarkan dapat mengakibatkan gangguan pencernaan lainnya yang lebih serius seperti impaksi dan infeksi saluran kemih atau pada keadaan yang lebih lanjut adalah terjadinya kanker kolon dimasa yang akan datang (Potte\&Perry, 2009; Syahny, 2012).

\section{Hubungan Konsumsi Serat dengan Pola BAB}

Dalam penelitian ini sebagian besar responden mengonsumsi serat kurang dari 20-31 $\mathrm{g} /$ hari dan memiliki frekuensi BAB yang dari 4-9 kali dalam semiggu dan sumber serat paling banyak dikonsumsi didapatkan dari roti tawar. Roti tawar merupakan salah satu produk makanan hasil olahan tepung terigu yang berasal dari gandum-ganduman yang mengandung serat tinggi (O'Neil et. al, 2010). Berdasarkan Panduan Acuan Nutrisi Canada's Food Guide to Healthy Eating asupan serat yang paling banyak adalah berasal dari sereal dan bulir padi utuh yaitu $23,4 \mathrm{~g} /$ cangkir.

Selain dari gandum-ganduman, serat juga dapat diperoleh dari buah-buahan dan sayuran yang di sarankan dalam Canada's Food Guide to Healthy Eating pengonsumsiannya sebanyak 5-10 porsi per hari. dalam 1 porsi sayur atau buah hanya mengandung serat kurang dari 2 gram sehingga agar terpenuhi kebutuhan serat per hari maka dibutuhkan 5 porsi buahbuahan dan 5 porsi sayur-sayuran dalam sehari (Kozier et. al, 2010).

Didalam sistem pencernaan, serat tidak dapat diserap oleh tubuh karena berbentuk selulosa. Kurangnya konsumsi serat dapat mengakibatkan konstipasi, namun jika dikonsumsi secara berlebihan akan memberikan efek negatif. Sifat serat yang menahan reabsorpsi cairan dan elektrolit dapat menyebabkan tubuh kekurangan cairan dan elektrolit karena cairan dan elektrolit yang harusnya di serap oleh tubuh akan terbuang bersama feses. Serat yang tidak mengandung energi atau nutrien juga akan menyebabkan tubuh kekurangan zat gizi. Didalam kolon, serat akan difermentasi oleh bakteri yang berada disana dan akan menghasilkan gas sehingga perut akan terasa kembung (Juffrie dkk, 2012).

Dalam penelitian ini, konsumsi serat pada responden didapatkan rata-rata kurang dari $10 \mathrm{~g} / \mathrm{hari}$. Penelitian ini sesuai dengan hasil beberapa peneliti di Indonesia yang menyebutkan konsumsi serat pada anak usia sekolah masih rendah yakni di bawah $15 \mathrm{~g} / \mathrm{hari}$ (Puspamika\&Ni Ketut Sutiari, 2014). Konsumsi serat yang rendah ini dapat menyebabkan konstipasi dan jika tidak ditangangi dengan baik dalam jangka waktu yang panjang dapat mengakibatkan kanker kolon (Danjo et. al, 2008; Potter\&Perry, 2009). 
Berdasarkan hasil penelitian Diane E. Carson dan Wendy Reiboldt (2010) 67\% otang tua dari 755 responden setuju untuk mengikuti keinginan anak dalam pemilihan makanan. Hal ini berdampak positif kepada kebiasaan konsumsi makanan keluarga jika anak-anak mereka diberikan pendidikan kesehatan terlebih dahulu. Selain itu, sekolah juga memiliki peran yang penting dalam menyediakan makanan yang bergizi. Berdasarkan hasil penelitian Harrison, Jennings, Jones, et. al (2011) sekolah yang menyediakan makanan siang memberikan kontribusi yang signifikan dalam memberikan diet makanan yang sehat dibandingkan dengan sekolah yang hanya menyediakan makanan-makanan dalam kemasan.

\section{KESIMPULAN}

Responden yang mengonsumsi karbohidrat lebih dari $220 \mathrm{~g} /$ hari memiliki frekuensi BAB yang lebih normal (4-9 kali dalam seminggu) di bandingkan dengan yang mengonsumsi karbohidrat dalam batas cukup (120-220 g/hari). Dari hasil output chi square test diperoleh hasil X2 hitung sebesar 4.878 dengan nilai signifikansi (Asymp. Sig. (2-sided)) sebesar 0,087. Dari hasil statistik tersebut maka dapat disimpulkan bahwa tidak terdapat hubungan antara konsumsi karbohidrat terhadap pola BAB.

Hampir semua responden yang mengonsumsi serat kurang dari $20 \mathrm{~g} /$ hari memiliki frekuensi BAB kurang dari 4 kali dalam seminggu sebanyak $52 \%$. Berdasarkan hasil output chi square test diperoleh hasil $\mathrm{X} 2$ hitung sebesar 1.094 dengan nilai signifikansi (Asymp. Sig. (2sided)) sebesar 0,296. Dari hasil statistik tersebut, maka dapat disimpulkan bahwa antara konsumsi serat dengan pola BAB tidak terdapat hubungan.

\section{SARAN}

Konsumsi makanan dan eliminasi dalam kasus ini eliminasi fekal (BAB) merupakan salah satu kebutuhan dasar manusia yang harus terpenuhi oleh semua manusia agar terhindar dari rasa kurang yaman. Hal ini dapat kita perdalam ilmunya dalam keperawatan dasar.

Selain itu, hasil penelitian ini dapat digunakan sebagai bahan pertimbangan untuk melakukan penelitian lainnya yang masih dianggap kurang dalam penelitian ini seperti cara pengukuran aktivitas pada anak usia sekolah.

Perawat di puskesmas sebagai pengontrol kesehatan masyarakat di wilayah kerjanya dapat membuat program penyuluhan tentang manfaat dan pengaruh makanan tinggi serat dan asupan cairan serta membuat leaflet untuk disebarluaskan. Sedangkan untuk sekolah dapat memfasilitasi untuk diadakannya penyuluhan kepada seluruh siswa dan orang tua atau wali murid. Selain itu, sekolah juga dapat menyediakan jajanan yang tinggi serat seperti buahbuahan segar. Selain itu, makanan-makanan ini dapat diolah dengan mempercantik tampilannya atau dicampurkan dengan makanan kesukaan anak-anak seperti agar-agar atau jelly. Dalam menyajikan makanan, orang tua juga dapat melibatkan anak-anaknya untuk membantu memotong atau mengupas sayuran atau membiarkan anak untuk berkreasi dengan bahan-bahan makanan yang disediakan. Hal ini dapat membuat anak menjadi senang dan bangga memakan hasil kreasinya.

\section{DAFTAR PUSTAKA}

Alexopoulos, Yvonne.2007. Nutrition Essentials and Diet Therapy. Saunders Elsevier: USA

Arikunto, Suharsimi. 2010. Prosedur Penelitian: Suatu Pendekatan Praktik. Rineka Cipta: Jakarta

Berman, Audrey et al. 2008. Fundamentals of Nursing: Concepts, Process, and Practice 8th ed. Pearson Education: United State of America

Brinkworth, G.D, et. al. 2009. Comparative Effects of Very Low-Carbohydrate, High-Fat and High-Carbohydrate, Low-Fat Weight-Loss Diets on Bowel Habit and Faecal Short-Chain 
Fatty Acids and Bacterial Populaitons. British Journal of Nutrition. Vol. 101. Halaman 14931502

Carson., and Wendy Reiboldt. 2010. Parents' Agreement to Purchase Healthy Snack Foods Requested by Their Children. JFCS. Volume 102

Corwin J., Elizabeth. 2009. Buku Saku Patofisiologi. EGC: Jakarta

Danjo, Kazuma et. al. 2008. Effects of Cellulose Supplementation on Fecal Consistency and Fecal Weight. Dig Dis Sci. Vol. 53. Halaman 712-718

Feferbaum et al. 2012. Fluid Intake Patterns: An Epidemiological Study Among Children and Adolescents in Brazil. BMC Public Health. Volume 12. Halaman 1005

Gage., and Fernandes Tanya. 2009. Understanding the Role of Probiotics in Supporting Digestive Comfort. Nursing Standard. Halaman 47

Harrison, Flo, et. al. 2011. Food and Drink Consumption at School Lunchtime: The Impact of Lunch Type and Contribution to Overall Intake in British 9-10 Year Old Children. Public Health Nutrition. Volume 16(6). Halaman 1132-1139

Hidayat, A. Aziz Alimul. 2006. Pengantar Kebutuhan Dasar Manusia Buku 2. Salemba Medika: Jakarta

Hokenberry, and David Wilson. 2011. Wong's Nursing Care of Infant and Children. Elsevier Mosby: USA

Jennings, Amy et al. 2010. Bowel Habit, Diet, and Body Weight in Preadolescent Children. Jurnal of Nutrition and Dietetics. Halaman 511-519

Juffrie, Mohammad, dkk. 2012. Buku Ajar Gastroenterologi-Hepatologi Jilid 1. UKK GASTROENTEROLOGI-HEPATOLIGI IDAI: Jakarta

Kozier, Barbara et. al. 2010. Fundamental of Nursing: Concepts, Process, and Practice 7th Edition Volume 2. EGC: Jakarta

Kurt, J. Isselbacher et al . 1999. Harrison: Prinsip-Prinsip Penyakit Dalam Vol. 1 Ed. 13. EGC: Jakarta

McGowan, Laura et al. 2013. Healthy Feeding Habits: Efficacy Result from a ClusterRandomized, Control Exploratory Trial of a Novel, Habit-Based Intervention with Parents. American Society for Nutrition. Halaman 769-777

Nakaji, Shigeyuki. et, al. 2002. Relationship Between Lifestyle Factors and Defecation in a Japanese Population. Eur Journal Nutrition ed. 41. Halaman 244-248

Notoatmodjo, Soekidjo. 2012. Metodologi Penelitian Kesehatan. Rineka Cipta: Jakarta

O'Neil et. al. 2010. Consumption of Whole Grains is Associated with Improved Diet Quality and Nutrient Intake in Children and Adolescents: the National Health and Nutrition Examination Survey 1999-2004. Public Health Nutrition ed. 14(2). Halaman 347-355

Palith, Somnath, Peter J. Lunniss, S. Mark Scott. 2012. The Physiology of Human Defecation. Springer Science Business Media. Volume 57. Halaman 1445-1464

Potter, and Anne G. Perry. 2005. Fundamental Keperawatan ed. 4 volume 2. EGC: Jakarta

Potter, and Anne G. Perry. 2009. Fundamental Keperawatan ed. 7 buku 3 . Salemba Medika: Jakarta

Puspamika, dan Ni Ketut Sutiari.2014. Konsumsi Serat pada Anak Sekolah di Kota Denpansar. Community Health. Volume II. Halaman 133-140

Putra, Sitiatava Rizema. 2012. Panduan Riset Keperawatan dan Penulisan IImiah. D-Medika: Yogyakarta

Ratnasari, dan Yekti Wirawani.2012. Gambaran Kebiasaan Konsumsi Mie Instan pada Anak Usia 7-12 Tahun. Journal of Nutrition College. Volume 1. Halaman 86-92

Rosdahl, Caroloine Bunkar.1999. Textbook of Basic Nursing 7th Edition. Lippincott: America

Schlenker, and Sara Long Roth. 2011. William's Essentials of Nutrition and Diet Therapy 10th ed. Elsevier Mosby: USA 
Sullivan B. P. et al. 2011. Effectiveness of Using a Behavioural Intervantion to Improve Dietery Fibre Intakes in Children with Constipation. Jurnal of Nutrition and Dietetics. Halaman 3342

Syahny, Irna Fajri. 2012. Konstipasi Kronis Sebagai Faktor risiko Terjadinya Infeksi Saluran Kemih pada Anak. Electronic Theses and Dissertations (FTD) UGM: Yogyakarta

Tirtawinata, Tien Ch. 2006. Makanan dalam Perspektif Al-Quran dan IImu Gizi. Balai Penerbit FKUI: Jakarta

Wong, D onna L. 2009. Buku Ajar Keperawatan Peditrik. EGC: Jakarta 